Katarzyna Bagan-Kurluta

\title{
ABOUT SURROGACY AGREEMENTS AGAINST A BACKGROUND OF AMERICAN EXPERIENCES
}

The story of surrogacy is as old as the Bible and since those ancient times, women have consistently been giving birth to other women's children. Not out of altruism or for material gain, but simply because they were forced into doing so. Maids and concubines were compelled into giving birth to children of their masters and artificial insemination was obviously out of the question and unrealizable ${ }^{1}-$ the method was both basic and socially unacceptable. In more recent history, developments in medicine in the field of artificial procreation, led first to artificial insemination and then to in vitro fertilization of an ovum for subsequent implant as an embryo into a woman's womb. Surrogacy remains as ever a fact but the method has changed - it is now much more sophisticated and with that sophistication, surrogacy has become socially respectable. Belief in the potential material benefits resulting from surrogacy agreements, added to differences in national laws, has created the phenomenon of reproductive tourism where surrogate mothers and egg donors started to be imported from Spain, Ukraine and the United States. The latter, together with India (since 2002, when compensated surrogacy was legalized), have also become popular places for surrogacy agreements' to be executed. ${ }^{2}$

Judging by the number of Internet offers from women willing to become prospective surrogate mothers, services of this kind are in great demand including here in Poland. In Poland, agreements are executed according to a mistakenly understood freedom of contract principle, mistakenly - because such agreements are null and void. This results for at least three reasons: 1) surrogacy agreements are in conflict with the principles of social coexistence which makes freedom of contract limited (together with conflicts of the substance or objectives of legal relationship with its nature and mandatory statutory provisions), according to art. $353^{1}$, and also

K.D. Krawiec, Altruism and Intermediation in the Market for Babies, 66 Wash. \&Lee L. Rev. 2009, p. 223. L.C. Ikemoto, Reproductive Tourism: Equality Concerns in the Global Market for Fertility Services, 27 Law\&Ineq., 2009 , p. 292, 297, also K.D. Krawiec, Altruism and Intermediation in the Market for Babies, 66 Wash. \&Lee L. Rev. 2009, p. 225. 
$58 \S 2$ of the Polish Civil Code ${ }^{3}, 2$ ) the inability to transfer parental authority by virtue of a contract, because freedom of contract does not cover family relations, 3) a contract transferring parental authority is that of impossible performance (art. 387 $\S 1$-impossibilium nulla obligatio). Furthermore, the Polish Family Code regulation does not give basis for action. According to art. 619 the mother of a child is the woman who gave birth to the child and denial of motherhood is feasible only in the case of an incorrect entry on the child's birth certificate (when the name of a women who did not give a birth to the child was listed on the certificate as the child's mother - art. $6112 \S 1){ }^{4}$ Similarly, any attempt to apply foreign law allowing to conclude a surrogacy agreement and accepting their validity and effectiveness will end in failure - because its application would have effects contradictory to fundamental principles of the Polish legal order. ${ }^{5}$

Taking into consideration the provisions of Polish law, parties to a surrogacy agreement are not able to take the position of parents of a child on the virtue of a contract. Still they can achieve it as a result of activities apparently not connected with the agreement (especially when the fact of its execution is hidden): 1) an intended mother pretends pregnancy, simulates giving birth to a child at home, and registers herself as the mother of the child, 2) the intended father, with the consent of the surrogate mother, recognizes fatherhood; the surrogate mother abandons her parental rights and turns the child over to him - he becomes the sole parent of the child, 3) a surrogate mother abandons her parental rights and gives consent for adoption by the intended parents; a family court deciding adoption, applies 'the best interest of a child' principle. The existence of an agreement is usually only revealed when a dispute arises between the intended parents and the surrogate mother. Presently it is hard to appraise the range of problems caused by uncontrolled surrogacy and beyond doubt, one should feel uneasiness about the deception of parentage and its consequences. The lack of effectiveness of surrogacy agreements causes a shortage of protection to the contracting parties - a surrogate mother can easily keep the child and decline to hand the child over to the intended parents; the intended parents can refuse to pay or at least reimburse costs and finally, they can refuse to take a sick child. Commenting on the foregoing problems one should notice that the first successful in vitro fertilization in Poland was carried out in $1987,{ }^{6}$ and still the issue of the introduction of artificial procreation regulation is one of extreme controversy and dispute. The first test-tube baby was born in 1978 in the United States, and of Civil Code: Journal of Laws 1964, No. 16, item 93 with subsequent amendments. Act of 6 November 2008 regarding a change of law - Family and Guardianship Code and some other acts, (Journal of Laws 2008, No. 220, item 1431.) subsequent amendments: Journal of Laws 1995 , No. 83 , item 417; 1999, No. 52, item 532): Foreign law shall not apply where application thereof would have effects contradictory to fundamental principles of legal order of the Polish People's Republic. 
maybe that is why American regulations regarding surrogacy agreements have the longest tradition.

Surrogacy contracts became the subject of wide interest and vivid scientific disputes owing to a case decided by the New Jersey Supreme Court in 1988 (in Re Baby M.). In this matter the Court was asked to determine the validity of a contract providing for consent of a woman to be artificially inseminated with the semen of another woman's husband for a fee of $\$ 10,000$. She was to conceive a child, carry it to term, and after the birth of the child surrender him/her to the biological father and his wife. The intent of the contract was that the child's biological mother would be forever separated from her child and that the biological father's wife was to adopt the child - she and the biological father would be regarded as the child's parents. In February 1985, William Stern and Mary Beth Whitehead entered into a surrogacy contract, because Stern's wife, Elizabeth, was infertile, they wanted a child and Mrs. Whitehead was willing to provide that child as the mother with Mr. Stern as the father. The contract was fulfilled - a child was born and surrendered to the Sterns. But just after separation from her child Mrs. Whitehead abandoned herself to despair. The depth of her despair surprised and frightened the Sterns. She told them that she could not live without her baby, that she must have her, even if only for one week, that thereafter she would surrender her child. The Sterns, concerned that Mrs. Whitehead might commit suicide, not wanting under any circumstances to risk that, and in any event believing that Mrs. Whitehead would keep her word, turned the child over to her. It was not until four months later, after a series of attempts to regain possession of the child, that Melissa was returned to the Sterns, having been forcibly removed from the home where she was then living with Mr. and Mrs. Whitehead, a home in Florida owned by Mary Beth Whitehead's parents - eventually the Sterns discovered where the Whiteheads were staying, commenced supplementary proceedings in Florida, and obtained an order requiring the Whiteheads to turn over the child. Police in Florida enforced the order, forcibly removing the child from her grandparents' home. She was soon thereafter brought to New Jersey and turned over to the Sterns. The trial court reaffirmed prior order of the court, issued ex parte, awarding custody of the child to the Sterns, after consideration of the certified representations of the parties (both represented by counsel) concerning the unusual sequence of events that had unfolded. Pending final judgment, Mrs. Whitehead was awarded limited visitation with Baby M. New Jersey Supreme Court invalidated the surrogacy contract because it was in conflict with the law and public policy of the State of New Jersey recognizing the depth of the yearning of infertile couples to have their own children and finding the payment of money to a "surrogate" mother illegal, perhaps criminal, and potentially degrading to women. The court granted custody to the biological father (the evidence having clearly proved such custody to be in the best interests of the infant), voided both the termination of the surrogate mother's parental rights and the adoption of the child by the wife/step-parent restoring the "surrogate" as the 
mother of the child and remanding the issue of the natural mother's visitation rights to the trial court. ' Since this verdict surrogacy contracts became popular - there were 600 cases of children born as a result of the contract. The gestational surrogacy contracts amounted to $95 \%$ of all the agreements ${ }^{8}$ (in gestational surrogacy the surrogate mother is not the biological contributor of the egg, in traditional surrogacy the surrogate mother is the biological contributor of $\left.i^{9}\right)$. Although surrogacy contracts generate many complex problems, there is no uniform regulation binding all states, or at least one model ruling for all of them in the United States. Attempts to unify the law (or rather to create a model law) were made several times - in 1973 (Uniform Parentage Act - already changed several times), ${ }^{10}$ in 1988 (Uniform Status of Assisted Conception Act - a woman who gives birth to a child is its mother unless the surrogacy agreement has been approved by a court before the child was born; if the agreement has not been approved by the court, it is void), and in 2008 (Model Act Governing Assisted Reproductive Technology)." American federal law does not address them: the state legislatures are competent to create the laws regarding surrogacy. According to the information given by M. Fras and D. Abłażewicz ${ }^{12}$ in 2008, there were 6 state laws allowing to execute surrogacy contracts (Arkansas, California, Illinois, Massachusetts, New Jersey and Washington), acts of state law and jurisprudence of 11 states and DC banned on their execution in any case or under certain conditions. According to next 34 state laws, it was uneasy to decide interchangeably about admissibility of the contracts. In the light of data provided by Human Rights Campaign, the numbers are slightly unlike the given data: ${ }^{13}$

1) in 10 states there are no statutes dealing directly with the issue of surrogacy, 2 ) in 24 states ( 26 with exceptions) it is accepted: a) in 9 states there are no statutes dealing directly with the issue of surrogacy but at least one court has acknowledged the parental rights of non-biological participants in a surrogacy arrangement, b) in 2 states there are no statutes dealing directly with the issue of surrogacy but various cases have looked favorably on such agreements, c) in 2 states there are no statutes dealing directly with the issue of surrogacy and uncompensated agreements may be permissible, d) in 4 states law permits married people to enter into a surrogacy agreement, e) in 1 state law permits married people to enter into a gestational surrogacy

In re Baby M, 537 A.2d 1227, 109 N.J. 396 (N.J. 02/03/1988), 537 A.2d 1227, 109 N.J. 396, 1988.NJ.41301 http://www.versuslaw.com, http://biotech.law.Isu.edu/cases/cloning/baby_m.htm. Also M. Gittleman, In the Matter of Baby M.: A Setback for Surrogacy Contracts, 40 Rutgers L. Rev. 1987-1988, p. 1313-1314. 
agreement, $\mathrm{f}$ ) in 1 state law permits married people to enter into an uncompensated surrogacy agreement, g) in 3 states law permits to enter into an uncompensated surrogacy agreement, h) in 1 state law permits to enter into an uncompensated gestational surrogacy agreement, i) in 1 state law permits to enter into a gestational surrogacy agreement, 3 ) in 3 (2) states the agreements are unenforceable: a) in 1 state there are no statutes regarding surrogacy but surrogate parenting agreements in general are unenforceable in the state, $b$ ) in 1 state all surrogacy contracts are against public policy and unenforceable,

c) in 1 state traditional surrogacy agreements are void and unenforceable, but gestational surrogacy agreements are legal and enforceable, 4) in 7 states law regarding surrogacy agreements is unclear: a) in 4 states the law is unclear, b) in 2 states the law is unsettled, however, various court decisions seem to indicate that some surrogacy agreements are considered lawful, c) in 1 state there is no specific law that addresses surrogacy agreements, related laws might hold compensated agreements unenforceable, 5) in 5 states and District of Columbia there is a ban on surrogacy agreements: a) in 1 state statutes do not address surrogacy agreements, but the ruling of at least one court suggests that those agreements go against the public policy of the state, b) in DC all surrogacy agreements are prohibited by law, c) in 1 state all surrogacy agreements are void and unenforceable, d) in 1 state all surrogacy agreements are prohibited by law - they are void and unenforceable, e) in 1 state compensated surrogacy agreements are void and unenforceable, but it is possible that the law would uphold uncompensated agreements, f) in 1 state compensated traditional surrogacy agreements are void and unenforceable, but law does not address uncompensated agreements or gestational surrogacy agreements.

The differences in laws signify the lack of consent to recognize surrogacy agreements as legal instruments. In states where they are accepted, they should be executed under control of the state (e.g. approval of a court) or in a way ensuring that they actually have been executed (e.g. a contract should be in writing). Inconsistency with public order is usually the reason to treat them as void. In states, where the laws do not deal with surrogacy contracts or surrogacy itself or other states where it is unclear how law would treat them - adjudicating courts can accept a freedom of procreation as a justification of contract execution. The essence of this freedom deriving from constitutional right to privacy is an opportunity to procreate through whatever means, in private. ${ }^{14}$ 'The court also engaged in a constitutional analysis [can find] the right to enter into a surrogacy contract protected by the Fourteenth Amendment under substantive due process (as part of the rights to privacy and to procreate). ${ }^{\prime}$ In absence of regulation a court dealing with a case of surrogacy and

14 Quoting Jeffrey Steinberg, director of the Fertility Institute, as stating that „[t]hese are grown-up people expressing their reproductive choices. We cherish that in the United States", in: Kimberly D. Krawiec, Altruism and Intermediation in the Market for Babies, 66 Wash. \& Lee L. Rev. 2009, p. 215. 
establishment of the parent - child relationship is able to take into consideration one of three ties ${ }^{16}$ - giving birth to a child, genetic relationship and 'intent to bring a child into the world and raise the child as one's own as part of a family unit, not by biology ${ }^{17}$ - and also the best interest of a child. A criterion of intent was applied in one of the most famous cases in the United States - Johnson v. Calvert. ${ }^{18}$ Husband and wife brought suit seeking declaration that they were legal parents of child born of woman in whom the couple's fertilized egg had been implanted. In 1993, California Supreme Court decided that a person who intended to procreate (an intended mother who was a donor of an egg) should be regarded as parent of a child in a case of gestational surrogacy agreement. Also in a very complex case from 1998 (In re Marriage of Buzzanca),${ }^{19}$ the court decided that in a consequence of procreation using the surrogate mother and genetically unrelated embryo implanted in her, as well as of intent to keep a child is recognition of parent-child relationship between a child and intended parents. As a matter of fact, the complexity of the case was prompted by a number of its participants - the surrogate mother was impregnated in a consequence of implantation of an egg of an anonymous donor fertilized by a sperm of an anonymous donor - so a court deciding about parentchild relationship had to choose from six parents-to-be: a donor of an egg, a donor of a sperm, intended mother, intended father, surrogate mother and her husband.

The courts in at least three states (Alabama, Arkansas, Connecticut) used to apply best interest of a child criterion - in cases regarding children not genetically related to the intended parents, also recognizing the right of a surrogate mother to withdraw from a contract and keep the child. ${ }^{20}$ In a Connecticut case from 1998 (Doe v. Doe ${ }^{21}$ ), the Supreme Court dealing with dispute of a wife and husband concerning custody of a child born in effect of a traditional surrogacy agreement, decided in favor of a wife because her role in child upbringing was enough to overcome the statutory presumption that it is in the child's best interests to be in the custody of a biological parent (in this case, either the husband or the surrogate mother).

Illinois (750 ILCS 47/1) Gestational Surrogacy Act ${ }^{22}$ is a fine example of the newest regulation, which is the most favorable for intended parents. It has been in force since January 2005, and its aim is to establish consistent standards and procedural safeguards for the protection of all parties involved in a gestational

L. Anderson, Adding Players to the Game: Parentage Determinations When Assisted Reproductive Technology is Used to Create Families, 62 Ark. L. Rev. 2009, p. 32.

Miller-Jenkins v. Miller-Jenkins, No. 454-11-03 Rddm, at 11 (Rutland Fain. Ct. Nov. 17, 2004).

5 Cal.4th 84, 851 P.2d 776, 19 Cal.Rptr.2d 494, 61 USLW 2721

61 Cal.App. 4th 1410 (1998).

H.J. Gitlin, Illinois Becomes Surrogacy Friendly, http://www.gitlin.com/pages/llinoisBecomesSurrogacyFriendly. html $(14 / 04 / 2010)$.

710 A.2d 1297 (Conn. 1998).

FAMILIES (750 ILCS 47/) Gestational Surrogacy Act, 14/04/2010, http://www.ilga.gov/legislation/ilcs/ilcs3.asp?A $\mathrm{ctID}=2613 \&$ ChapAct $=750 \% 26 \mathrm{nbsp} \% 3 \mathrm{BILCS} \% 26 \mathrm{nbsp} \% 3 \mathrm{~B} 47 \% 2 \mathrm{~F} \&$ ChapterID=59\&ChapterName=FAMILIES \& ActName $=$ Gestational + Surrogacy + Act. 
surrogacy contract in the state, and to confirm the legal status of children born as a result of these contracts - to facilitate the use of this type of reproductive contract in accord with the public policy of the state (state law allows for gestational surrogacy agreement, it does not regulate traditional surrogacy contracts). For the purposes of the act gestational surrogacy was defined as the process by which a woman attempts to carry and give birth to a child created through in vitro fertilization using the gamete or gametes of at least one of the intended parents and to which the gestational surrogate has made no genetic contribution. According to sec. 15, the woman who gives birth to a child is presumed to be the mother of that child for purposes of state law, except as provided in the act with respect to gestational surrogacy and the event of a laboratory error in which the resulting child is not genetically related to either of the intended parents. In the first case the intended mother is a mother of a child immediately upon the birth of the child, the intended father shall be the father of the child from the same moment and the child shall be considered the legitimate child of the intended parent or parents immediately upon the birth of the child. Parental rights shall vest in the intended parent or parents immediately upon the birth of the child. Sole custody of the child shall rest with the intended parent or parents immediately upon the birth of the child and neither the gestational surrogate nor her husband, if any, shall be the parents of the child immediately upon the birth of the child. In the second case the intended parents will be the parents of the child for purposes of state law unless otherwise determined by a court of competent jurisdiction. A gestational surrogate shall be deemed to have satisfied the requirements of the act if she has met the following requirements at the time the gestational surrogacy contract is executed: (1) she is at least 21 years of age, (2) she has given birth to at least one child, (3) she has completed a medical evaluation, (4) she has completed a mental health evaluation, (5) she has undergone legal consultation with independent legal counsel regarding the terms of the gestational surrogacy contract and the potential legal consequences of the gestational surrogacy and (6) she has obtained a health insurance policy that covers major medical treatments and hospitalization and the health insurance policy has a term that extends throughout the duration of the expected pregnancy and for 8 weeks after the birth of the child (the policy may be procured by the intended parents on behalf of the gestational surrogate pursuant to the gestational surrogacy contract). The intended parent or parents shall be deemed to have satisfied the requirements of the act if he, she, or they have met the following requirements at the time the gestational surrogacy contract is executed: (1) he, she, or they contribute at least one of the gametes resulting in a pre-embryo that the gestational surrogate will attempt to carry to term, (2) he, she, or they have a medical need for the gestational surrogacy as evidenced by a qualified physician's affidavit attached to the gestational surrogacy contract and as required by the Illinois Parentage Act of 1984, (3) he, she, or they have completed a mental health evaluation and (4) he, she, or they have undergone legal consultation with independent legal 
counsel regarding the terms of the gestational surrogacy contract and the potential legal consequences of the gestational surrogacy.

A gestational surrogacy contract should be in writing and two competent adults should witness it. It should be executed prior to the commencement of any medical procedures (other than medical or mental health evaluations necessary to determine eligibility of the parties pursuant to the act). Separate counsel in all matters concerning the gestational surrogacy and the gestational surrogacy contract should represent each of the gestational surrogate and the intended parent or parents. Each of them should sign a written acknowledgement that he or she received information about the legal, financial, and contractual rights, expectations, penalties, and obligations of the surrogacy agreement. If the gestational surrogacy contract provides for the payment of compensation to the gestational surrogate, the compensation should be placed in escrow with an independent escrow agent prior to the gestational surrogate's commencement of any medical procedure (other than medical or mental health evaluations necessary to determine the gestational surrogate's eligibility). A gestational surrogacy contract should provide for (as a minimum): (1) the express written agreement of the gestational surrogate to: (i) undergo pre - embryo transfer and attempt to carry and give birth to the child and (ii) surrender custody of the child to the intended parent or parents immediately upon the birth of the child. If she is married it should provide for the express agreement of her husband to: (i) undertake the obligations imposed on the gestational surrogate pursuant to the terms of the gestational surrogacy contract, (ii) surrender custody of the child to the intended parent or parents immediately upon the birth of the child. It should also provide for the right of the gestational surrogate to utilize the services of a physician of her choosing, after consultation with the intended parents, to provide her care during the pregnancy and the express written agreement of the intended parent or parents to: (i) accept custody of the child immediately upon his or her birth and (ii) assume sole responsibility for the support of the child immediately upon his or her birth. A gestational surrogacy contract shall be presumed enforceable even though it contains: (1) the gestational surrogate's agreement to undergo all medical exams, treatments, and fetal monitoring procedures that the physician recommended for the success of the pregnancy, (2) the gestational surrogate's agreement to abstain from any activities that the intended parent or parents or the physician reasonably believes to be harmful to the pregnancy and future health of the child, including, without limitation, smoking, drinking alcohol, using non-prescribed drugs, using prescription drugs not authorized by a physician aware of the gestational surrogate's pregnancy, exposure to radiation, or any other activities proscribed by a health care provider, (3) the agreement of the intended parent or parents to pay the gestational surrogate reasonable compensation and (4) the agreement of the intended parent or parents to pay for or reimburse the gestational surrogate for reasonable expenses 
(including, without limitation, medical, legal, or other professional expenses) related to the gestational surrogacy and the gestational surrogacy contract. In the event that any of the requirements are not met, a court of competent jurisdiction shall determine parentage based on evidence of the parties' intent. There shall be no specific performance remedy available for a breach by the gestational surrogate of a gestational surrogacy contract term that requires her to be impregnated.

Establishment of the parent - child relationship is possible as early as prior to the birth of a child born through gestational surrogacy if, in addition to satisfying the requirements of provisions of the Illinois Parentage Act of 1984, the attorneys representing both the gestational surrogate and the intended parent or parents certify that the parties entered into a gestational surrogacy contract intended to satisfy the requirements of the act with respect to the child. The attorneys' certifications should be filed on forms prescribed by the Illinois Department of Public Health and in a manner consistent with the requirement of the Illinois Parentage Act of 1984.

A lot of cases being decided by American courts have interstate character, which means that they are connected with more than one state. Thus the courts have to examine the issue of application of foreign law and validity or effectiveness of the agreements in states, where they are prohibited or not accepted. Apart from methods combining various ideas, there are four main theories and at the same time methods of choice of law in the United States:

a) vested rights theory (exploited in The Restatement (First) of Conflict of Laws), applied in 13 states, b) governmental interest analysis (applied in three states), proposed by B. Currie in the fifties of XX century - according to which, a court should analyze laws connected with a case and determine which one is the most interested in application of its own rules (after determination of the laws connected with a case a court should consider the circumstances (factors/contacts) possibly linking a case with the laws determined, if a predominant number of circumstances connects a case with one law, this law should be applied; in the cases raising doubts - there should be a determination of governmental interests of the states and ascertainment by application of what rules can be accomplished; ${ }^{23} \mathrm{c}$ ) better law theory known also as a choice influencing factors theory, proposed by $\mathrm{R}$. Leflar in the sixties of XX century, and applied in five states; using this method a court analyzes problem of application of law in a case taking into consideration the following factors: 1) predictability of results, 2) maintenance of interstate \& international order, 3) simplification of the judicial task, 4) advancement of the forum's governmental interests, 5) application of the better rule of law: ${ }^{24}$

23 B. Currie, Selected Essays on the Conflict of Laws, Duke University Press, Durham, N.C. 1963, K. Bagan-Kurluta, Prawo prywatne międzynarodowe, Warszawa 2006, p. 33-36.

24 See: R.A. Leflar, The Law of Conflict of Laws, Indianapolis, New York 1959. 
In a Minnesota case from 2007, Minnesota Court of Appeals analyzed the district court decision regarding the choice-of-law issue by using the choice-influencing factors (and arrived at the same conclusion by a different analysis). Appellant, who served as the gestational surrogate for respondent's child, challenged the district court's determination of parentage and custody in favor of respondent, arguing that the district court 1) erred by enforcing the parties' gestational-surrogacy agreement, 2) erred by applying Illinois law as provided by the choice-of-law provision in the parties' agreement and then incorrectly applied Illinois law, and 3) abused its discretion by granting respondent's request to change the child's name. The record supported the district court's findings and it did not err in its application of the law, what the Minnesota Court of Appeals affirmed. Respondent, P.G.M., was a 38-yearold attorney, who lived in New York City. Raised in a large family, P.G.M. wanted to have a child. As a gay man with HIV, P.G.M. spent more than a year discussing the procedure with doctors, considering possible egg donors, and researching gestational surrogacy, he believed that the only method to produce a genetically related child was by using in vitro fertilization and a gestational surrogate (the district court found that P.G.M.'s disease was successfully controlled, that he was in excellent physical health, and that he had a normal life expectancy for a man his age). After one of his doctors expressed a preference for a biologically related gestational surrogate, P.G.M. called his sister Mary during the spring of 2004 to ask if she would serve that function. Mary declined, but she told appellant J.M.A., Mary's daughter and a student in Minnesota, about her conversation with P.G.M. Although J.M.A. was pregnant at the time, she made an unsolicited call to P.G.M. and offered to act as his gestational surrogate. Aware that J.M.A. was then pregnant, P.G.M. declined J.M.A.'s offer. Over the next several months, the parties exchanged correspondence about gestational surrogacy. After J.M.A. gave birth to her child in the fall of 2004, P.G.M. accepted J.M.A.'s oral offer to act as his gestational surrogate. On December 2, 2004, P.G.M. signed a gestationalsurrogacy agreement (GSA) that he had drafted to memorialize the parties' agreement, using a sample that he had found on the Internet as a guide. The GSA provided that it was to be governed by Illinois law and contained the core terms of the agreement, specifically, that J.M.A. would carry P.G.M.'s genetic child, give birth to the child, and disclaim any right to the child. It also contained P.G.M.'s agreement, in return, to pay all of J.M.A.'s unreimbursed and incidental expenses associated with the surrogacy. The GSA also included disclosures about P.G.M.'s HIV, the 'sperm-washing' process (it cleanses the seminal fluid surrounding the donor's sperm and replaces it with a sterile solution. The district court found that sperm-washing minimizes the likelihood of the transmission of HIV to the gestational surrogate;) and this declaration of intent: I, [J.M.A.] hereby acknowledge that I have agreed to carry and give birth to a child conceived via in vitro fertilization through the union of an anonymous donor's ovum/ ova and [P.G.M.'s] sperm, so that [P.G.M.] may have a child genetically related to him. I have no intention of having physical or legal custody or any parental rights, duties or 
obligations with respect to any child born of this gestational surrogacy process. Rather it is my intention that the genetic and intended parent, [P.G.M.], shall exclusively have such custody and all parental rights, duties and obligations. In mid-December 2004, approximately a month after receiving a copy of the agreement, J.M.A. signed it after declining P.G.M.'s offer to have independent legal counsel review the document at P.G.M.'s expense. As part of an oral modification of the agreement, P.G.M. agreed to pay J.M.A. a $\$ 20,000$ fee for her services as a gestational surrogate. P.G.M. delivered a check for $\$ 20,000$ to J.M.A. at the end of December 2004. In early 2005, the parties traveled to an Illinois medical facility specializing in sperm-washing and invitro fertilization, and they signed in Illinois numerous releases and disclosures that the facility required in order to perform the procedure. On April 12, 2005, in vitro fertilization specialists in Illinois fertilized an egg from an anonymous donor with P.G.M.'s sperm and implanted the fertilized egg into J.M.A. During the summer of 2005, J.M.A. stayed for two months with P.G.M. in his New York City apartment. At some point during this stay, the parties had a falling out. Soon thereafter, J.M.A. demanded that P.G.M. pay her an additional $\$ 120,000$, and threatened to abort the child if P.G.M. did not meet her demands. In early December 2005, J.M.A. drafted a new GSA, which provided for additional compensation for transportation, medical, and psychological services. P.G.M. did not sign the revised GSA. On December 17, 2005, J.M.A. gave birth to the child in Minnesota. She named the child and did not tell P.G.M. about the child's birth, his name, or his whereabouts. After learning about the child's birth from his sister, P.G.M. filed this paternity action on December 19, 2005. The district court immediately appointed an attorney for J.M.A. from the office of the Hennepin County Public Defender. At the direction of the district court, Hennepin County Court Services interviewed both parties and filed a report that recommended that P.G.M. have temporary custody of the child. That report also noted that P.G.M. had a strong emotional attachment to the child but that J.M.A. was motivated in large part by the prospect of financial gain. A trial was held at which the district court heard extensive testimony and considered numerous exhibits. The district court issued its paternity findings of fact and conclusions of law on August 18, 2006, concluding that, under the Illinois Parentage Act, P.G.M. was the child's father and denying J.M.A. parental rights. ${ }^{25}$

d) the most significant relationship (Second Restatement) method, applied in 27 states $^{26}$ (its goal is to search for state which is the most significantly connected with

In re Paternity\&Custody of Baby Boy A., No. A07-452, 2007 WL 4304448 (Minn. Ct. App. Dec. 11, 2007), Hennepin County District Court File No. 27-PA-FA-05-278S, see http://www.lawlibrary.state.mn.us/archive/ctapun/0712/opa070452-1211.htm. Also S. Bychkov Green, Interstate Intercourse: How Modern Assisted Reproductive Technologies Challenge the Traditional Realm of Conflicts of Law, 24 Wis. J. L. Gender\&Soc'y 2009, p. 95-97.

26 S. Symeonides, Choice of Law In the American Courts in 2004: Eighteenth Annual Survey, $52 \mathrm{Am}$. J. Comp. L. 2004, p. 944, S. Bychkov Green, Interstate Intercourse: How Modern Assisted Reproductive Technologies Challenge the Traditional Realm of Conflicts of Law, 24 Wis. J. L. Gender\&Soc'y 2009, p. 95-97. 
a case, using following steps: 1) determination of the area of law: a) substance or procedure, than b) characterization; 2) taking into account factors which are specific for certain groups of cases (for contracts, according to Restatement (Second) of Conflict of Laws s. 187(2) (1971): (2) The law of the state chosen by the parties to govern their contractual rights and duties will be applied, even if the particular issue is one which the parties could not have resolved by an explicit provision in their agreement directed to that issue, unless either (a) the chosen state has no substantial relationship to the parties or the transaction and there is no other reasonable basis for the parties' choice, or (b) application of the law of the chosen state would be contrary to a fundamental policy of a state which has a materially greater interest than the chosen state in the determination of the particular issue and which, under the rule of s. 188 , would be the state of the applicable law in the absence of an effective choice of law by the parties.; 3) consideration of factors illustrating the most significant connection with a case (according to The Restatement (Second) of Conflict of Laws s. 188 (1971): In the absence of an effective choice of law by the parties, the contacts to be taken into account in applying the principles of s. 6 to determine the law applicable to an issue include: a) the place of contracting, b) the place of negotiation of the contract, c) the place of performance, d) the location of the subject matter of the contract, and e) the domicile, residence, nationality, place of incorporation and place of business of the parties (these contacts are to be evaluated according to their relative importance with respect to the particular issue); 4) application of principles from sec. 6 of Second Restatement: needs of interstate system, policies of forum, policies of other states, justified expectations, basic polices underlying this field of law, certainty, predictability \& uniformity and ease in determination. ${ }^{27}$

The fine example of application of the most significant relationship method is Hodas v. Morin case from Massachusetts (2004): The plaintiffs were a married couple residing in Connecticut, the gestational carrier (mother) and her husband, both nominal defendants, resided in New York. The hospital, the other nominal defendant, was a licensed Massachusetts hospital whose statutory duties included, among others, reporting information concerning births at the hospital to the city or town clerk where the birth occurred. In April, 2003, the plaintiffs, the gestational carrier, and the gestational carrier's husband entered into a fifteen-page "Contract Between a Genetic Father, a Genetic Mother, a Gestational Carrier and Her Husband" (gestational carrier agreement). The parties represented that each had been advised by counsel of their choice prior to entering into the agreement. Among other things, the gestational carrier agreement provided that any child resulting from the agreement would be delivered at the hospital, if at all possible and that in any event the gestational carrier

S. Bychkov Green, Interstate Intercourse: How Modern Assisted Reproductive Technologies Challenge the Traditional Realm of Conflicts of Law, 24 Wis. J.L. Gender\&Soc'y 2009, p. 87-90, for fragments of Second Restatement see: http://masscases.com/cases/sjc/442/442mass544.html 
would "take all reasonable steps to give birth to any child carried pursuant to this Agreement at a Hospital located in the State of Massachusetts." It is undisputed that the parties chose Massachusetts as the site of the birth in part to facilitate obtaining a pre-birth order. The parties' preference for Massachusetts was further expressed in the following choice of law provision: "The Gestational Carrier and [her] husband agree that they are entering into this Agreement with the intention that in accordance with the laws of the State of Massachusetts, they will take whatever steps are necessary to have the Genetic Father and the Genetic Mother named as the natural, legal and genetic parents, to have the Genetic Father and the Genetic Mother named as the father and mother, respectively, of [the] child on the child's birth certificate, and to permit the Genetic Father and the Genetic Mother to obtain physical custody of any child born as the result of this Agreement. [...] The parties further agree that this Agreement shall be governed by Massachusetts law." Approximately six months after the parties entered into the gestational carrier agreement, the gestational carrier was successfully implanted with an embryo produced from the male plaintiff's sperm and the female plaintiff's egg. The implantation took place in Connecticut. The gestational carrier received at least some prenatal care at the hospital. At oral argument on June 30, 2004, counsel informed the court that an induced delivery was planned at the hospital the following week, and finally a child was born there. A Probate and Family Court judge decided about lack of authority to issue pre-birth judgments of parentage and to order the issuance of a pre-birth record of birth where neither the genetic parents nor the gestational carrier with whom they contracted to bear a child reside in Massachusetts, but where the contract specifies that the birth occur at a Massachusetts hospital. The genetic parents' (plaintiffs) uncontested equity action for a declaration of paternity and maternity and for a pre-birth order was dismissed. The judge then reported her decision to the Appeals Court. On June 22, 2004, a single justice of the Appeals Court enjoined the defendant (hospital), from issuing any birth certificate for a child born of the gestational carrier, or filing the same with the Commissioner of Public Health.

The verdict of the Supreme Judicial Court, dealing with a case as a court of appeal, was different - the court decided to list the names of intended parents on child's birth certificate. First the court had to consider the issue of proper law to be applied - so to answer the question about possibility to recognize choice of law as an effective one, when done by persons not being residents of the state, when the laws of Connecticut, New York, and Massachusetts, the three states that potentially could govern the agreement, were not in accord. In Connecticut, where the genetic parents resided, gestational carrier agreements were not expressly prohibited by, and perhaps might be contemplated by, the amended statute governing the issuance of birth 
certificates. ${ }^{28}$ The gestational carrier resided in New York, a State that had expressed a strong public policy against all gestational carrier agreements..$^{29}$ Massachusetts recognized gestational carrier agreements in some circumstances. ${ }^{30}$ In light of these differing State policies and the parties' declared intent to follow Massachusetts law, the court looked to established "functional" choice of law principles and to the Restatement (Second) of Conflict of Laws, with which those principles generally were in accord. ${ }^{31}$ The Restatement similarly presumes that the law the parties have chosen applies, unless "(a) the chosen state has no substantial relationship to the parties or the transaction and there is no other reasonable basis for the parties' choice, or (b) application of the law of the chosen state would be contrary to a fundamental policy of a state which has a materially greater interest than the chosen state" and is the State whose law would apply under s. 188 of the Restatement "in the absence of an effective choice of law by the parties." Under the analysis of the Restatement the court concluded that Massachusetts had a "substantial relationship" to the transaction. That substantial relationship was anchored in the parties' negotiated agreement for the birth to occur at a Massachusetts hospital and for a Massachusetts birth certificate to issue, and bolstered by the gestational carrier's receipt of prenatal care at a Massachusetts hospital in anticipation of delivery at that hospital (place of partial performance was considered to be sufficient to establish a reasonable basis for the parties' choice of law). Then the court analyzed a question whether applying the parties' choice of law would be "contrary to a fundamental policy" of another state with a "materially greater interest." Certainly the interests of New York and Connecticut were material and significant, for the contracting parties resided in these States. Nevertheless, the interests of New York and Connecticut might be at cross purposes. New York, the home of the gestational carrier and her husband, expressly prohibited gestational carrier agreements in order to protect women against exploitation as gestational carriers and to protect the gestational carrier's potential parental rights. New York had expressed a "fundamental policy" on a matter in which it had a great interest. Connecticut, the plaintiffs' home state, was silent on the question of gestational carrier agreements, but in any event did not expressly prohibit the plaintiffs from entering into such an arrangement. Massachusetts also had interests, including interests in "establishing the rights and responsibilities of

See: Conn. Gen. Stat. C. 93, s. 7-48a, 2004 Conn. Legis Serv. PA. 04-255 (West 2004) („On and after January 1,2002 , each birth certificate shall contain the name of the birth mother, except by the order of a court of competent jurisdiction...").

See: N.Y. Dom. Rel. Law s. 122 (McKinney 1999) („Surrogate parenting contracts are hereby declared contrary to the public policy of this state, and are void and unenforceable").

See: Culliton v. Beth Israel Deaconess Med. Ctr., supra; R.R. v. M.H., 426 Mass. 501 (1998)

Bushkin Assocs., Inc. v. Raytheon Co., 393 Mass. 622, 631-632 (1985). As a rule, „[w] ]here the parties have expressed a specific intent as to the governing law, Massachusetts courts will uphold the parties' choice as long as the result is not contrary to public policy." Steranko v. Inforex, Inc., 5 Mass. App. Ct. 253, 260 (1977), citing Restatement (Second) of Conflict of Laws s. 187 (1971). See Morris v. Watsco, Inc., 385 Mass. 672, 674 (1982) („Massachusetts law has recognized, within reason, the right of the parties to a transaction to select the law governing their relationship") 
parents [of children born in Massachusetts] as soon as was practically possible" and "furnishing a measure of stability and protection to children born through such gestational surrogacy arrangements." However, even if the court was to decide that New York had a "materially greater interest" than both Connecticut and Massachusetts, New York's policy would not operate to overrule the parties' choice of law unless New York would have been the applicable law in the absence of any articulated choice by the parties. The Restatement (Second) of Conflict of Laws s. 187(2)(b) directed the court to a list of factors enumerated in s. 188 to determine what law would have applied if the contract itself were silent on the issue. Consideration of the factors listed in s. 188 lead to inconclusive results. For example, the "place of contracting" and the "place of negotiation," were both unknown, although presumably these activities took place in New York or Connecticut, or both. The "place of performance" arguably was the intended place of birth (Massachusetts), or the place of prenatal care (at least partly in Massachusetts), or the place where the pregnancy evolved (New York), or the place where the genetic carrier was inseminated (Connecticut), or any combination of these. The location of the "subject matter of the contract" was equally difficult to determine, and the final consideration, the "domicile" of the parties (New York or Connecticut) in this case was not helpful. Thus, whatever New York's interest in protecting the gestational carrier and her husband, it was doubtful that the principles of s. 188 would result in application of New York law to this particular contact. Where the significant contacts are so widely dispersed that determination of the state of the applicable law without regard to the parties' choice would present real difficulties, the Restatement instructs that the parties' choice of law will be honored. This conclusion comported with functional conflict of laws analysis, which required consideration of factors such as "uniformity of result, maintenance of interstate order, and simplification of the judicial task" and "the justified expectations of the parties." The judge (of a Probate and Family Court) should have applied the parties' choice of law, the law of Massachusetts, to resolve the plaintiffs' complaint. Although the judge in her decision prudently raised the issue of forum shopping in declining to consider the complaint, in the circumstances of this case, the parties' choice of law was one that should be respected. ${ }^{32}$

There are a lot of pros and cons in discussion regarding validity and effects of surrogacy agreement in the United States - it seems that the voices of antagonists prevail. Protagonists say that surrogacy is the simplest, in a medical sense, procedure (traditional surrogacy), which allows infertile couple to have a child genetically related (gestational surrogacy) -a healthy infant of the same race and color. Moreover - as in a case of the state of Illinois - it is possible to gain the status 
of a parent of a child even before a child is born. Based on that, it may be concluded, that there is no necessity to conduct an adoption lawsuit in court when the intended parents' names can be listed on a child's birth certificate. There is an advantage to pre-birth establishment of parenthood, especially in dealing with control of the child immediately after the birth, removing the child from hospital, insuring the child ${ }^{33}$. Protagonists try to dispel fears concerning admissibility of the contracts using the argument of constitutional freedom of procreation covering also the surrogacy and artificial insemination as its instruments. Surrogacy is condemned as aiming at concept of traditional family - permission to join this family by a third person brings about lack of ability to explain ties between the members of the family with the help of reference to biological relation between a child, his mother and father ${ }^{34}$.

It is an instrument which enables separation of biological maternity and paternity from a genetic one, and biological from a legal one (biological tie between a child and surrogate mother results from pregnancy and giving birth of a child by her, while a child is genetically related to someone else ${ }^{35}$ ), and also biological maternity from maternity in social sense. Even in 1995 judge Gerber, deciding in the case: Soos v. Superior Court $^{36}$ said that maternity is a certain fact, so its establishment in nowadays seems not to be a practical problem. In the 1999 edition of Black's Law Dictionary, notion 'mother' was defined as: a woman who gave birth to a child or adopted a child, in order to add one more meaning of a notion five years later: a woman who provided the egg for (donor of an egg). There were also some entries added: biological mother, birth mother, genetic mother, gestational mother, intended mother, natural mother and surrogate mother. ${ }^{37}$ Three women, who can be regarded as mother of a child, can participate in surrogacy - the one who is genetically related to a child, the one who gave birth to a child and finally the one who has planned a pregnancy with an intention to keep a child born as a result of this pregnancy. ${ }^{38}$ Before the methods of artificial procreation were developed at least two of these ties (if not three of them) existed between one woman and a child. ${ }^{39} \mathrm{~A}$ child can also have three fathers. As a result of statutory provisions containing presumption of paternity of a certain man (husband of a mother or intended father), according to a law and despite the intention of all concerned - a child can be treated as an

H.J. Gitlin, Illinois Becomes Surrogacy Friendly, http://www.gitlin.com/pages/IllinoisBecomesSurrogacyFriendly. html (14/04/2010).

M.R. Mellown, An Incomplete Picture: The Debate about Surrogate Motherhood, 8 Harv. Women's L.J. 1985, p. 232.

L.C. Ikemoto, Reproductive Tourism: Equality Concerns in the Global Market for Fertility Services, 27 Law\&Ineq., 2009, p. 285.

Soos v. Superior Court ex rel. County of Maricopa, 897 P.2d 1356 (Ariz. Ct. App. 1994).

C.P. Kindregan Jr., Considering Mom: Maternity and the Model Act Governing Assisted Reproductive Technology, 17 Am. U.J. Gender Soc. Pol'y\& L. 2009, p. 602.

L. Tritt, Sperms and Estates: An Unadulterated Functionally Based Approach to Parent-Child Property Succession, 62 S.M.U.L.Rev. 2009, p. 390.

L. Anderson, Adding Players to the Game: Parentage Determinations When Assisted Reproductive Technology is Used to Create Families, 62 Ark. L. Rev. 2009, p. 32. 
offspring of two perfect strangers. As a consequence, there is a good chance that a parent-child relation will be established between a child, surrogate mother and an intended father. Execution of a surrogacy agreement complicates family relations. ${ }^{40}$ Instead of two biological parents, we have more people concerned and participating in surrogacy procedure: a) two persons (surrogate mother and intended father when a sole parentage of a father is possible in the light of law (e.g. in Arkansas, when intended father is unmarried and also a donor of sperm, ${ }^{41}$ also according to a judgment In Re Robert d.B. ${ }^{42}$ (Maryland) a maternity of surrogacy mother can be denied by reason of necessity to grant the same rights to both - mother and father of a child, despite the argument that a child should not be deprived of a mother), b) three persons (surrogate mother and intended parents). However in gestational surrogacy can participate: a) three persons (surrogate mother, intended mother who is also a donor of an egg, intended father who is also a donor of a sperm), b) four persons (surrogate mother, intended mother, a donor of an egg and intended father), c) five persons (surrogate mother, intended mother, a donor of an egg, intended father and a donor of a sperm). If we also add a husband of a surrogate mother to this group of people - we will have six persons instead of two from biological family. ${ }^{43}$

Surrogacy is also a menace for adoption - as surrogacy is better than adoption of a child of unknown origin or a child of a different race. The complexity of problems connected with surrogacy induces the necessity to give it careful consideration with regard to selling babies, adoption by stepmother, artificial insemination by a sperm donor (e.g. in statutes of 19 states there is a presumption of paternity of a mother's husband - so providing a sperm does not make a father out of a donor), custody of a child and establishment of parent-child relation. During surrogacy procedure there is a place for the economic exploitation of women by institutions dealing with searching for surrogate mothers, matching them with intended parents, intermediating in execution of agreements etc. Women take a risk for their physical condition and mental health (taking hormones which may produce side effects and possibly pose long term health risks, even hard to verify or identify now, but also being pregnant or giving birth to a child ${ }^{44}$ ) and social position. Women are also objectified - they became instruments in a struggle against infertility, in fact - they started to be a medicine for it.

40

M. Fras, D. Abłażewicz, Reżim prawny macierzyństwa zastępczego na tle porównawczym, „Problemy Współczesnego Prawa Międzynarodowego, Europejskiego i Porównawczego”, vol. VI, 2008, p. 43.

41

42

43

44

ARK. CODE ANN. §§ 9-10-201, 301, 304 (2009).

923 A.2d 115, 117-20 (Md. 2007).

Look at the information concerning the methods of artificial reproduction to be utilized in surrogacy: S. Bychkov Green, Interstate Intercourse: How Modern Assisted Reproductive Technologies Challenge the Traditional Realm of Conflicts of Law, 24 Wis. J.L. Gender\&Soc'y 2009, p. 35.

L.C. Ikemoto, Reproductive Tourism: Equality Concerns in the Global Market for Fertility Services, 27 Law\&Ineq. 2009, p. 304. 
To bring this article to a close, many people in Poland pretend that the phenomenon of surrogacy and surrogacy agreements does not exist. Circumvention of adoption rules, creation of fictitious circumstances, deception of parentage - all of this happens owing to lack of proper regulation.

Despite critical voices relating to surrogacy and the shortcomings of surrogacy agreements, the most important fact is that it gives a chance to attain a goal that is otherwise impossible to reach - being the parent of a genetically related newborn. The American way of establishing parent-child relations before a child is born in part provides a guarantee that the parties to an agreement will not change their minds. Indeed, there are many reasons why the Illinois act can be treated as a source for model regulation: simple procedure leading to obtaining the child's birth certificate, establishment of family relations before a child is born (a child can be taken from a hospital, insured, parents have custody etc.), the parent-child relation is established immediately - there is no need for court or administrative action, no requirements regarding domicile or residency of the parties, no demands for the intended parents to be married. ${ }^{45}$ 


\section{ABOUT SURROGACY AGREEMENTS AGAINST BACKGROUND OF AMERICAN EXPERIENCES}

The development of medicine in the field of artificial procreation enabled artificial insemination of woman's egg and also implementation of an inseminated embryo to her womb. Belief in the potential material benefits resulting from surrogacy agreements added to differences in national laws have caused a phenomenon of reproductive tourism.

Judging the number of Internet offers from women willing to become prospective surrogate mothers, services of this kind are in great demand including here in Poland. Although agreements are executed according to a mistakenly understood freedom of contract principle, mistakenly - because such agreements are null and void.

American regulations regarding surrogacy agreements have the longest tradition. Although surrogacy contracts generate many complex problems, there is no uniform regulation binding all states, or at least one model ruling for all of them in the United States. The differences in laws signify the lack of consent to recognize surrogacy agreements as legal instruments.

In states where they are accepted, they should be executed under control of the state or in a way ensuring that they actually have been executed. Inconsistency with public order is usually the reason to treat them as void. In states, where the laws do not deal with surrogacy contracts or surrogacy itself or other states where it is unclear how law would treat them - adjudicating courts can accept freedom of procreation as a justification of contract execution.

The finest example of the newest American regulation is the Illinois Gestational Surrogacy Act, which is the most favorable for intended parents.

Key words: surrogacy, surrogacy agreement, intended parent, validity, public order 


\section{O UMOWACH SUROGACJI W OPARCIU O AMERYKAŃSKIE DOŚWIADCZENIA}

Rozwój medycyny w dziedzinie sztucznej prokreacji umożliwił sztuczne zapłodnienie komórki jajowej kobiety i wprowadzenie do jej organizmu w ten sposób zapłodnionej gamety. Natomiast przekonanie o potencjalnych korzyściach majątkowych wynikających z umowy surogacji wraz z różnicami w prawach krajowych spowodowały powstanie zjawiska turystyki reprodukcyjnej.

Sądząc po ilości internetowych ofert kobiet chętnych do zostania potencjalnymi matkami zastępczymi, na usługi tego rodzaju istnieje duże zapotrzebowanie. Również w Polsce, mimo że umowy surogacji są zawierane zgodnie z błędnie rozumianą swobodą kontraktowania, błędnie - ponieważ takie umowy są nieważne.

Amerykańskie regulacje dotyczące umów zastępczych mają najdłuższe tradycje. Chociaż umowy surogacji mogą generować wiele złożonych problemów, brak jest tam jednolitego rozwiązania obowiązującego we wszystkich stanach, lub przynajmniej jednego modelu regulacji. Różnice w prawach stanowych oznaczają brak zgody na uznanie umów za powszechnie stosowany instrument prawny.

W stanach, w których są dopuszczalne, powinny być zawierane pod kontrolą państwa lub w sposób gwarantujący, że rzeczywiście zostały zawarte. Sprzeczność z porządkiem publicznym jest zazwyczaj przyczyną ich nieważności. W stanach, w których prawo nie odnosi się do umów surogacji lub do samego rodzicielstwa zastępczego oraz w stanach, w których stanowisko prawa w kwestii surogacji jest niejasne, sąd orzekający w sprawie może zaakceptować wolność prokreacji jako uzasadnienie dla zawarcia takiej umowy.

Dobrym przykładem najnowszej amerykańskiej regulacji dotyczącej surogacji jest Illinois Gestational Surrogacy Act, najbardziej korzystny dla tzw. socjologicznych rodziców, który jednocześnie mógłby służyć jako model dla przyszłych rozwiązań prawnych. 